\title{
Use of intra-articular autologous platelet concentrates as coadjutants in the surgical arthroscopy treatment of elbow dysplasia in a bitch
}

\author{
Uso intra-articular de concentrados autólogos de plaquetas como coadyuvantes en el tratamiento \\ artroscópico de una displasia de codo en una perra
}

\section{RF Silva ${ }^{\text {ab* }}$, JU Carmona ${ }^{a}$, CMF Rezende ${ }^{b}$}

\author{
${ }^{a}$ Grupo de Investigación Terapia Regenerativa, Departamento de Salud Animal, Universidad de Caldas, Colombia. \\ ${ }^{\mathrm{b}}$ Departamento de clinica e cirurgia veterinárias, Escola de Veterinária, Universidade Federal de Minas Gerais, Brasil.
}

RESUMEN

\begin{abstract}
La displasia del codo canino (CED) es un complejo de enfermedades que resultan en (OA) osteoartritis. CED incluye la no unión del proceso ancóneo (UAP), fragmentación del proceso coronoides medial (FMCP), osteocondritis (OC) del cóndilo medial del húmero e incongruencia del codo. Una perra con OC del cóndilo medial del húmero y FMCP fue tratada por artroscopia mediante microfracturas del hueso subcondral y remoción, respectivamente, y recibió dosis intra-articulares de concentrados autólogos de plaquetas (APC). La paciente fue evaluada mediante examen clínico, citología del líquido sinovial, evaluación radiográfica y evaluación en plataforma de fuerza, antes de la cirugía y a los 15, 30, 60 y 90 días postoperatorios. La paciente alcanzó recuperación clínica completa al 60 día postoperatorio, acompañado de mejoría en la citología del líquido sinovial y en los resultados cinemáticos. Sin embargo, la evaluación radiológica mostró un leve desarrollo de OA. Los resultados de este informe pueden sugerir el potencial de uso de APC como una terapia de acción modificadora sintomática en el tratamiento de OA secundaria a la displasia de codo en el perro.
\end{abstract}

Palabras clave: perro, plasma rico en plaquetas, displasia de codo, osteoartritis.

\section{SUMMARY}

Canine elbow dysplasia (CED) is a complex of diseases resulting in osteoarthritis (OA). CED includes ununited anconeal process (UAP), fragmented medial coronoid process (FMCP), osteochondritis (OC) of the medial humeral condyle, and elbow incongruity. A patient with OC of the medial humeral condyle and FMCP was treated by arthroscopy for micro-fractures of subchondral bone and removal, respectively, and received intra-articular doses of autologous platelet concentratres (APC). The patient was evaluated by clinical examination, synovial fluid cytology, radiographic assessment and platform force evaluation, before surgery and at 30,60 and $90^{\text {th }}$ postoperative days. The patient reached full clinical recovery at 60 th postoperative day with improvement in the synovial fluid cytology and the kinematic findings. However, radiological evaluation showed a progressive development of OA. Results from this report may suggest the potential-use of APC as a symptomatic modifying therapy in the treatment of OA secondary to elbow dysplasia in the dog.

Key words: dog, platelet rich plasma, elbow dysplasia, osteoarthritis.

\section{INTRODUCTION}

Canine elbow dysplasia (CED) is a term used to describe developmental orthopedic conditions resulting in elbow osteoarthritis (OA), such as ununited anconeal process (UAP), fragmented medial coronoid process (FMCP), osteochondritis (OC) of the medial humeral condyle, and elbow incongruity, either alone or in combination (Trostel et al 2003). CED is a common cause of forelimb lameness and occurs frequently in 4-6 month old dogs from medium to large body size. The etiology and pathogenesis of CED is not completely understood, although genetics, either nutritional excesses or deficiencies, growth distur-

Accepted: 21.03.2013

* Calle 65 No 26-10, Manizales, Caldas, Colombia; raul.silva@ ucaldas.edu.co bances, $\mathrm{OC}$ and, trauma are proposed causes (Demko and McLaughlin 2005). To date, CED is managed by combining the specific surgical treatment in conjunction with diminution of the body weight, physiotherapy and administration of oral non-steroidal anti-inflammatory drugs and nutraceutical agents (Beale 2004).

Autologous platelet concentrates (APC) (also known as platelet-rich plasma -PRP-) are source of growth factors (GFs) such as transforming growth factor beta (TGF-ß), platelet-derived growth factor (PDGF) and other proteins modulating inflammation and tissue repair (Argüelles et al 2006). APC have been widely used in human and veterinary procedures. Recent results have shown that APC can be used safely to treat OA in horses (Carmona et al 2009) and human beings (Kon et al 2009, Filardo et al 2011). Further, recently was described the use of autologous conditioned plasma (a kind of PRP) 
as an adjunct treatment in the arthroscopic management of OC injury in the shoulder in a dog with encouraging results (Neumann and Viefhues 2010).

The aim of this paper was to describe the use of APC as adjunctive therapy in a case of elbow dysplasia in a dog, which was operated by arthroscopic surgical technique. The novelty of this report lies in the fact that encouraging results were obtained from the patient, confirmed by force platform gait analysis, cytological characteristics of synovial fluid and minimal radiographic progression of degenerative joint changes during the first 90 postoperative days.

\section{MATERIAL AND METHODS}

\section{CASE DESCRIPTION}

A 4-month-old intact Rottweiler bitch weighing 21.8 $\mathrm{kg}$ was admitted at the facilities of the authors with history of lameness of right forelimb with 2 weeks of duration. During the clinical examination the patient showed marked lameness of the right forelimb and synovial effusion of the elbow joint. Mediolateral (ML) and anteroposterior (AP) elbow radiographies showed the presence of a lesion compatible with osteochondritis (OC) of the medial portion of the humeral condyle. Arthroscopy confirmed elbow OC and additionally, revealed the presence of fragmented medial coronoid process (FMCP) (figure 1).

\section{PREPARATION OF APC AND SURGICAL PROCEDURE}

To prepare APC, whole blood was obtained by saphenous vein venipuncture with a $21 \mathrm{G}$ butterfly catheter (Becton Dickinson and Company, New Jersey, USA). Blood was collected into a $8.5 \mathrm{~mL}$ tube with $1.5 \mathrm{~mL}$ ACD-A solution (trisodium citrate $22 \mathrm{~g} / \mathrm{L}$, citric acid 8 $\mathrm{g} / \mathrm{L}$ and dextrose $24.5 \mathrm{~g} / \mathrm{L}$ ) (Becton Dickinson and Company, New Jersey, USA). Samples were centrifuged at

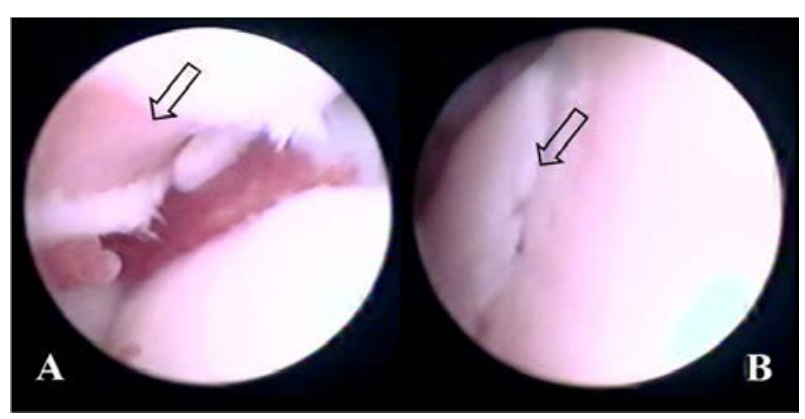

Figure 1. Osteochondritis (OC) of the medial portion of the humeral condyle (A), fragmented medial coronoid process (FMCP) (B) of right forelimb of Rottweiler breed dog.

Osteocondritis (OC) de la porción medial del cóndilo humeral (A), fragmentación medial del proceso coronoide (FMPC) (B) del miembro anterior derecho de un perro de raza Rottweiler.
$191 \mathrm{~g}$ for 6 minutes. One $\mathrm{mL}$ of plasma adjacent to the erythrocyte-plasma interface was collected using an $18 \mathrm{G}$ spinal needle. APC were activated with $0.1 \mathrm{~mL}$ calcium gluconate $(9.3 \mathrm{mg} / \mathrm{mL})$ (Ropsohn Therapeutics $®$ Ltda, Bogotá, Colombia) (Silva et al 2011). The cellular content (platelets and leukocytes) of the APC was analyzed by hemogram (Abacus Junior Vet, Austria) and compared with cell counts in whole blood by a paired t test with a significance level of $95 \%$.

During the arthroscopy, the FMCP was removed. However, the cartilage flap related with OC lesion was eliminated, but a portion was lost in the articulation and was not found. Further, micro-fractures were performed on the osteochondral defect. Then, $1 \mathrm{~mL}$ of APC was injected into the joint. The patient received anti-inflamatory treatment with firocoxib $(5 \mathrm{mg} / \mathrm{Kg}$ ) for 4 days. No physiotherapy protocols were included. APC injections were repeated for two additional times at two week intervals (Carmona et al 2009). Synovial fluid samples for cytological analysis and mucin quality determination were taken prior to APC injection and at 60 and 90th postoperative days.

\section{RADIOGRAPHIC AND FORCE PLATE ASSESSMENTS}

Serial time (before surgery and at 15, 30, 60 and, 90 ${ }^{\text {th }}$ postoperative days) radiographic evaluation was performed according to the grading definitions of the international elbow world group (IEWG) (0: normal; 1: elbow incongruence $>2 \mathrm{~mm}$, osteophytes $<2 \mathrm{~mm}$, osteoclerosis; 2: osteophytes 2-5 mm, suspect of primary cause; 3 : osteophytes $\geq 5 \mathrm{~mm}$, positive primary cause) (Hazewinkel and Nap 2009).

Force plate evaluation was performed at a walk on a track 3 meters long, $50 \mathrm{~cm}$ wide and $10 \mathrm{~cm}$ high. Ground reaction vertical forces acting between the limb and the force platform were evaluated in the stance phase of gait cycle. The patient walked at her own pace (average speed $1.74 \pm 0.07 \mathrm{~m} / \mathrm{s}$ ). Walking speed was calculated based on the cycle time of the left hindlimb, using the formula: speed = step frequency (cycles / s) x gait length (m) (Bertram and Ruina 2001). Three valid cycles for every limb were used. A cycle was considered as valid when both ipsilateral limbs were supported. Data were acquired at a rate of $300 \mathrm{~Hz}$ and processed with the DASYLab 10 program (Measurement Computing, USA). The assessed values were peak vertical reaction force $\left(\mathrm{Pf}_{\mathrm{z}}\right)$ and vertical impul-

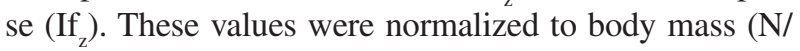
$\mathrm{kg}$ and $\mathrm{N} / \mathrm{kg} / \mathrm{s}$, respectively). Each variable was expressed as a percentage of the total force-impulse exerted by all limbs for this was used the formula: $\mathrm{X} \%_{(\operatorname{limb} \mathrm{A})}=\mathrm{F}_{(\text {limb A) }}$ / $\left(\mathrm{F}_{(\text {limb A) }}+\mathrm{F}_{\text {(limb B) }}+\mathrm{F}_{\text {(limb C) }}+\mathrm{F}_{(\text {limb D) }}\right)$, where $\mathrm{X} \%$ is the percentage of body mass distributed through the limb, limbs A, B, C and D represent the dog's four limbs and F represent force-impulse value of the limb being evaluated (Katic et al 2009). We calculated the mean value of three gait cycles per limb and these values were used for the gait analysis. 


\section{RESULTS AND DISCUSSION}

Platelet count in APC was significantly $(\mathrm{P}=0.01)$ higher $\left(589 \pm 141 \times 10^{3}\right.$ platelets $\left./ \mu \mathrm{L}\right)$ in comparison with whole blood count $\left(418 \pm 80 \times 10^{3}\right.$ platelets $\left./ \mu \mathrm{L}\right)$. Leukocyte count in APC was significantly $(\mathrm{P}=0.01)$ lower $(5.4 \pm$ $1.5 \times 10^{3}$ cells $/ \mu \mathrm{L}$ ) in comparison with whole blood count $\left(9.4 \pm 0.4 \times 10^{3}\right.$ cells $\left./ \mu \mathrm{L}\right)$. After each intra-articular APC injection, the patient showed local inflammation and lameness during first $12 \mathrm{~h}$. Inflammation produced in this patient may be due to proteins secreted by the $\alpha$-granules playing a part on inflammation, such as receptor expression that facilitates adhesion of platelets to vascular cells and other cells with the release of a wide range of chemokines. P-selectin, which moves from the $\alpha$-granules to the surface membrane of platelets after activation, participates in platelet interactions with endothelial cells, monocytes, neutrophils and lymphocytes. The $\alpha$-granules also play a role on inflammation by secreting of high concentrations of pro-inflammatory factors and immune modulation. These mediators induce the recruitment, activation and secretion of chemokines. Of these, CXCL4 has been reported to induce neutrophil adhesion and degranulation, monocyte activation and differentiation of macrophages and foam cells and numerous studies show that CXCL7 induce neutrophil chemotaxis (Blair and Flaumenhaft 2009).

Radiographic evaluation was grade 3 on day 0 , due to the primary lesion. Radiographic changes of the elbow joint from first to $90^{\text {th }}$ post-operative day, showed progressive development of osteophytes of the coronoid process and dorsal border of the anconeal process regions and, increased sclerosis of the trochlear notch and the caudal and lateral borders of the distal humerus (figure 2). Synovial fluid cytology presented gradual improvement during time (table 1).

Peak vertical reaction force and If values became more homogeneous from the $60^{\text {th }}$ post treatment day, eventually reaching values that were very similar between contralateral limbs at the $90^{\text {th }}$ postoperative day. Before treatment, the distribution of body mass on $\mathrm{Pf}_{\mathrm{z}}$ values showed an overload on the left ipsilateral limbs, especially the left forelimb. The percentages of limb support began to present homogeneous values from the $60^{\text {th }}$ day and, presented values practically similar at the $90^{\text {th }}$ postoperative day, with a relative distribution approximately of $60 \%$ for forelimbs and $40 \%$ for hindlimbs (table 2).

There is an increased use of platelet related products for the treatment of knee OA in human beings (Kon et al 2009, Filardo et al 2011). Platelet concentrates have also been used for the treatment of OA and OC in horses (Carmona et al 2009). The rationale for the use of this regenerative therapy lies in the fact that platelet concentrates are a source of anabolic growth factors for chondrocytes and synoviocytes, such as TGF- ${ }_{1}$ and PDGF, amongst others (Argüelles et al 2006). TGF- ${ }_{1}$ possesses a powerful antiinflammatory effect in joints and promotes the differentiation of synovial stem cells in cartilage (Pei et al 2009). All this clinical and basic background was taken into account for treating the patient of this report with APC.

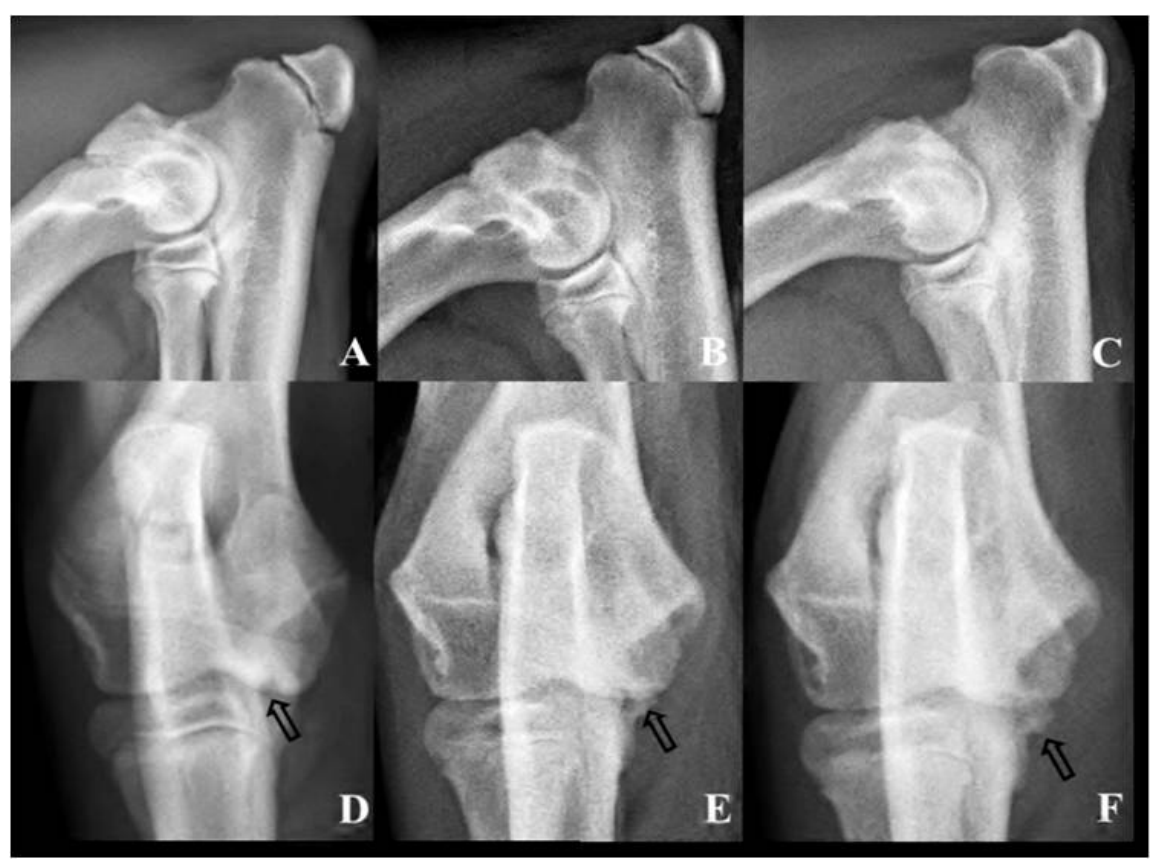

Figure 2. Medial-lateral (A, B, and C) and antero-posterior (D, E, and F) radiographs of the patient, before (A and D) and 60 (B and $\mathrm{E})$ and $90(\mathrm{C}$ and $\mathrm{F})$ postoperative days.

Radiografías medial-lateral (A, B y C) y antero-posterior (D, E y F) de la paciente, antes (A y D) y a los 60 (B y E) y 90 (C y F) días del posoperatorio. Flecha D, daño OCD; Flecha E y F, Osteofito. Arrow D, OCD injury; Arrow E and F, Osteophyte. 
Although the radiographic results indicate a slight OA progression, the clinical, cytological, and kinematic results observed in the bitch in this report could suggest the clinical use of APC as adjunctive therapy for canine elbow dysplasia. For the authors, it is not typical to find a canine elbow joint affected with severe $\mathrm{OC}$ of the medial humeral condyle and FMCP with moderate radiographic progression of OA at the $90^{\text {th }}$ post-operative day, as it was observed in this case. It is well recognized that the prognosis for medical or surgical treatment of a canine elbow affected by OC is guarded, because OA progression remains as an inevitable sequel (Demko and McLaughlin 2005).

The sequential cytological evaluation of the synovial fluid showed a time related improvement of the all evaluated parameters (table 1). These cytological findings, added to the clinical improvement of the patient, suggest that APC improves both cellular and rheological composition of the synovial fluid. Although the hyaluronan concentration in synovial fluid was not measured in this report, it is possible that APC have induced the local production of this substance in the joint environment of this patient, since mucin quality test improved during time. In addition, an in vitro study demonstrated that the addition of platelet concentrates to human osteoarthritic synoviocytes could increase the production of hyaluronan for these cells (Anitua et al 2007).

Clinic assessment and kinematic (gait) evaluation of the degree of lameness in the patient of this report showed a gradual improvement in the locomotion (walking) and complete improvement (no lameness) at the $90^{\text {th }}$ post-operative day. Under normal conditions, the forelimbs support approximately 60\% of body mass (Budsberg et al 1987, Lee et al 1999), condition that our patient reached almost at the $60^{\text {th }}$ postoperative day and, interestingly without receiving any other medical treatment such as NSAID or nutraceuticals. It must be pointed out that in another study, the use of electrostimulated acupuncture (ESA) as a treatment of dogs with clinical signs of forelimb lameness and radiographic evidence of chronic elbow joint OA secondary to CED did not have significant effect on the severity of lameness (Kapatkin et al 2006), as determined by measurement of vertical ground reaction forces, while the joint injection of APC improved the degree of lameness in our clinical case at the $60^{\text {th }}$ postoperative day.

Table 1. Results of synovial fluid cytology analysis.

Resultados del análisis citológico del líquido sinovial.

\begin{tabular}{|c|c|c|c|c|c|c|c|c|}
\hline Day & $\begin{array}{c}\text { Volume } \\
\mathrm{mL}\end{array}$ & Color & Turbidity & Viscosity & $\mathrm{TNCC} / \mu \mathrm{L}$ & $\mathrm{RBCC} / \mu \mathrm{L}$ & $\begin{array}{c}\text { Total Protein } \\
\text { g/dL }\end{array}$ & Mucin Clot \\
\hline 0 & 2 & Reddish & Cloudy & Moderate & 20000 & 256000 & 3.4 & Poor \\
\hline 30 & 0.9 & Reddish & $\begin{array}{l}\text { Slightly } \\
\text { Cloudy }\end{array}$ & High & 850 & 21000 & 3 & Good \\
\hline 60 & 0.5 & Clear & Colorless & High & 150 & 2500 & 2.4 & Good \\
\hline 90 & 0.5 & Clear & Colorless & High & 150 & 2500 & 2.4 & Good \\
\hline
\end{tabular}

TNCC: Total Nuclear Cell Count; RBCC: Red Blood Cell Count.

Table 2. Percentage body mass distribution of peak vertical force $\left(\mathrm{Pf}_{\mathrm{z})}\right.$ and vertical impulse $\left(\mathrm{If}_{\mathrm{z}}\right)$ in each limb, before surgery and up to 90 postoperative days.

Porcentaje de distribución de la masa corporal en el pico de fuerza vertical $\left(\mathrm{Pf}_{z}\right)$ e impulso vertical (If $)$ en cada miembro, antes de la cirugía y hasta 90 días post-operación.

\begin{tabular}{|c|c|c|c|c|c|}
\hline Variable & Time (days) & RFL* & LFL & RHL & LHL \\
\hline \multirow{5}{*}{$\mathrm{Pf}_{\mathrm{z}}$} & 0 & 22.80 & 37.53 & 19.80 & 19.87 \\
\hline & 15 & 11.65 & 28.05 & 31.93 & 28.37 \\
\hline & 30 & 15.48 & 30.96 & 20.54 & 33.01 \\
\hline & 60 & 25.18 & 31.35 & 20.62 & 22.85 \\
\hline & 90 & 29.85 & 30.31 & 20.01 & 19.83 \\
\hline \multirow{5}{*}{ If $_{z}$} & 0 & 23.86 & 33.63 & 27.81 & 14.70 \\
\hline & 15 & 12.59 & 30.19 & 30.91 & 26.31 \\
\hline & 30 & 18.86 & 33.11 & 21.09 & 26.94 \\
\hline & 60 & 22.77 & 25.88 & 21.87 & 29.48 \\
\hline & 90 & 27.58 & 29.26 & 23.72 & 19.44 \\
\hline
\end{tabular}

RFL: right forelimb; LFL: left forelimb; RHL: right hind limb; LHL: left hind limb. BMD: body mass distribution. *Treated limb. 
The results described in this report may suggest the safe potential use of APC as an intra-articular regenerative therapy with modifying action on the clinical signs of OA. The same observation was proposed for horses with joint disease (Carmona et al 2009). However, it is necessary to perform double-blind randomized controlled trials in the long term to demonstrate the therapeutic potential of this substance as an adjunct to surgical treatment of elbow dysplasia in dogs.

\section{REFERENCES}

Anitua E, M Sanchez, AT Nurden, MM Zalduendo, M De la Fuente, J Azofra, I India. 2007. Platelet-released growth factors enhance the secretion of hyaluronic acid and induce hepatocyte growth factor production by synovial fibroblasts from arthritic patients. Rheumatology 46, 17691772.

Argüelles D, JU Carmona, J Pastor, A Iborra, L Viñals, P Martínez, E Bach, M Prades. 2006. Evaluation of single and double centrifugation tube methods for concentrating equine platelets. Res Vet Sci 81, 237-245.

Beale BS. 2004. Use of nutraceuticals and chondroprotectants in osteoarthritic dogs and cats. Vet Clin Small Anim 34, 271-289

Bertram JEA, A Ruina. 2001. Multiple walking speed-frequency relations are predicted by constrained optimization. $J$ TheorBiol 209, 445-453

Blair P, R Flaumenhaft. 2009. Platelet $\alpha$-granules: Basic biology and clinical correlates. Blood Rev 23, 177-189.

Budsberg SC, MC Verstraete, RW Soutas-Little. 1987. Force plate analysis of the walking gait in healthy dogs. Am J Vet Res 48, 915-918.

Carmona JU, C Lopez, M Prades. 2009. Use of autologous platelet concentrates obtained by the tube method as a treatment for arthropathies in horses. Arch Med Vet 41, 175-179.

Demko J, R McLaughlin. 2005. Developmental orthopedic di- sease. Vet Clin Small Anim 35, 1111-1135.

Filardo G, E Kon, R Buda, A Timoncini, A di Martino, A Cenacchi, PM Fornasari, S Giannini, M Marcacci. 2011. Platelet-rich plasma intra-articular knee injections for the treatment of degenerative cartilage lesions and osteoarthritis. Knee Surg Sports Traumatol Arthrosc 19, 528-535.

Hazewinkel HAW, RC Nap. 2009. Elbow dysplasia, definition and known aetiologies. Proceedingas of the $24^{\text {rd }}$ Annual Meeting IEWG, Sao Paulo, Brasil, Pp 6-18.

Kapatkin AS, M Tomasic, J Beech, C Meadows, RC Boston, PD Mayhew, MY Powers, GK Smith. 2006. Effects of electrostimulated acupuncture on ground reaction forces and pain scores in dogs with chronic elbow joint arthritis. $J$ Am Vet Med Assoc 228, 1350-1354.

Katic N, BA Bockstahler, M Mueller, C Peham. 2009. Fourier analysis of vertical ground reaction forces in dogs with unilateral hind limb lameness caused by degenerative disease of the hip jointand in dogs without lameness. Am J Vet Res 70, 118-126.

Kon E, R Buda, G Filardo, A di Martino, A Timoncini, A Cenacchi, PM Fornasari, S Giannini, M Marcacci. 2009. Platelet-rich plasma: intra-articular knee injections produced favorable results on degenerative cartilage lesions. Knee Surg Sports Traumatol Arthrosc 18, 472-479.

Lee DV, JEA Bertram, RJ Todhunter. 1999. Acceleration and balance in trotting dogs. J Exp Biol 202, 3565-3573.

Neumann S, G Viefhues. 2010. Intraartikuläre Injektion von autologem Thrombozytenkonzentrat bei der OCD. Veterinärspiegel 1, 22-26.

Pei M, D Chen, J Li, W Lei. 2009. Histone deacetylase 4 promotes TGF- $\beta$ 1-induced synovium-derived stem cell chondrogenesis but inhibits chondrogenically differentiated stem cell hypertrophy. Differentiation 78, 260-268

Silva RF, CMF Rezende, FO Paes-Leme, JU Carmona. 2011. Evaluation of the tube method for concentrating canine platelets: cellular study. Arch Med Vet 43, 95-98.

Trostel CT, RM McLaughlin, RR Pool. 2003. Canine elbow dysplasia: anatomy and pathogenesis. Compend Contin Educ Pract Vet 25, 754-762. 
